\title{
Biocompatible Material from Indonesian Natural Resource of Wild Silkmoth Cocoon
}

\author{
Tjokorda Gde Tirta Nindhia $^{{ }^{*}}$, Zdeněk Knejzlík $^{2}$, Tomáš Ruml ${ }^{2}$, I Wayan Surata ${ }^{1}$, Tjokorda Sari Nindhia ${ }^{3}$ \\ ${ }^{1}$ Program Study of Mechanical Engineering, Engineering Faculty, Udayana University, Jimbaran, Bali, Indonesia \\ ${ }^{2}$ Institute of Chemical Technology, Prague, Technická 5, 166 28, Prague, Czech Republic \\ ${ }^{3}$ Faculty of Veterinary Medicine, Udayana University, Denpasar, Bali, Indonesia \\ *Corresponding author: nindhia@yahoo.com/tirta.nindhia@me.unud.ac.id
}

\begin{abstract}
Silk can be produced by spider or insect and have prospect as biomaterial for regenerative healing in medical treatment. Silk having physical and chemical properties that support biocompatibility in the living things. In this research, silk that was obtained from Indonesia natural resource of Attacus atlas silkmoth was explored and then will be developed for biocompatible biomaterial. The treatment with $\mathrm{NaOH}$ was developed to separate the fiber from the cocoon. The obtained fiber is investigated its mechanical property by performing tensile test for single fiber. The biocompatibility testing was conducted with human cell (osteosarccoma) cultivation. The result identify that separation by using $\mathrm{NaOH}$ yield better better mechanical properties comparing konvenstional method with boiling in hot water. Biocompatibility testing indicate that the the fiber having good biocompatibility.
\end{abstract}

Keywords: Silk, wild, Attacus atlas, mechanical properties, biocompatibility

\section{INTRODUCTION}

Natural silk is an interesting material for application in biotechnology and biomaterial that is obtained from spiders or insect $[1,2,3]$. Silk exhibit unique properties such high tensile strength with good properties of biocompatibility $[4,5]$. The research related with silk biomaterial commonly uses silk that is obtained from the species of domesticated Bombyx mori. This species was domesticated more than 4000 years ago and historically for use as material for fabrics [6].

Fiber obtained from cocoon of silk mainly contain complex fibroin which is produced by labial glands [7]. Around 10-12 $\mu \mathrm{m}$ fibroin fiber of Bombyx mori contain amorphous protein that is sericin which is released from cocoon by washing with weak alkali or hot water. The process of releasing fiber from cocoon is so called degumming [8]. Fine fiber that is obtained from degumming process can be used as source of fibroin. The fibroin can be dissolved with lithium salt, calcium nitrate or organic ion liquid. A liquid fibroin can be fabricated for fiber, sheet or three dimension product with pore (sponge) [9].

There species other than Bombyx mori dan can also produced silk with unique properties that cannot be found in the Bombyx mori one. For Example is Antheraea pernyi that have better property in cell cultivation feline fibroblast [10]. Also with species Antheraea mylitta as well, that have better property for the growth and attachment for cardiomyocytes from mouse postnatal [11].

Unique attachment properties of A. mylitta fibroin matrix is caused by content of short amino acid RGD motif in the molecule [12]. The tensile strength of silk obtained from silkmoth cocoon compared with silk from spiders, especially spiders from species of Nephila was found different [13]. Method to release the fiber from the cocoon (degumming) influent the properties of the silk $[14,15]$.

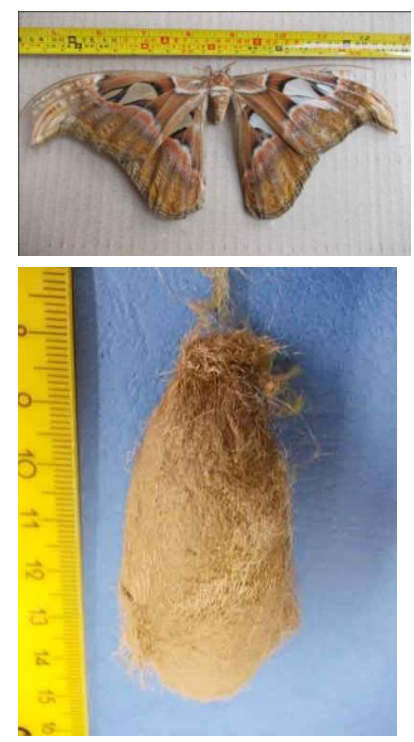

Fig. 1. The cocoon of silkmoth of Attacus atlas and appearance of the silkmoth.

In this research, the cocoon from species of Attacus atlas silkmoth (Fig. 1) is taken as a source of silk fiber that was degummed by using $\mathrm{NaOH}$ solution. The fiber obtained will be tested its biocompatibility troughs growth of human cell osteosarcoma (U2OS). The tensile test is performed to discover the mechanical property of single fiber. 


\section{RESEARCH METHODS}

The cocoons of silk-moth Attacus atlas were prepared from Indonesian sources. The Cocoon was boiled in ). $1 \mathrm{M}$ of $\mathrm{NaOH}$ for 1 hour. The fibers obtained by using this process were cleaned with hot water. The $50 \mathrm{mg}$ of fiber clean fibers were sterilized in ethanol for 12 hours at room temperature. Afterward, the samples are washed with 4 time repetition with PBS and then separate from the PBS solution with vacuum suction.

.The Fiber then was immersed for 2 hours in to the suspension of U2OS cell with media cultivation of DMEM with supplement of $10 \%$ FBS $\left(10^{5}\right.$ cell per $\left.\mathrm{ml}\right)$. The atmosphere was $5 \% \mathrm{CO}_{2}$, at temperature $37^{\circ} \mathrm{C}$ and $95 \%$ humidity. The cell cultivation was conducted for 6 days. Observation of cell growth of the fiber was carried out by taking the fiber from cultivation media and cleaned twice with PBS

The tensile test was conducted by following tensile test method for single silk fiber $[16,17,18]$. The $5 \mathrm{~cm}$ length of single fiber was glued in the cardboard frame with distance $30 \mathrm{~cm}$ (regarded as gauge length). The tensile test was performed by using screw test stand with constant speed. The balance with resolution $\pm 10 \mathrm{mg}$ was mounted at the bottom of the cardboard frame of the tensile test to measure the load as similar with loas cell. The testing was performed at $30^{\circ} \mathrm{C}$ and $60 \%$ relative humidity.

Cell on the fiber surface was fixed with $4 \%$ formaldehyde in PBS for 20 minutes and washed twice. The cell nucleus was stained with $1 \mu \mathrm{g} / \mathrm{ml}$ DAPI (SigmaAldrich, USA) and actin microfilaments with $10 \mu \mathrm{g} / \mathrm{ml}$ phalloidin conjugate with TRITC in PBS solution for 20 minutes at room temperature. The observation was performed by using fluorescence microscope

\section{RESULTS AND DISCUSSION}

The Attacus atlas fiber contained with bonding material together with fibrillar material as depicted in Fig. 2. The bonding material is removed completely (Fig.3) with $\mathrm{NaOH}$ treatment with concentration $0.1 \mathrm{M}$. It is found the tensile strength of the fiber is higher if treated with $\mathrm{NaOH}$ compared the one with conventional degummed method with boiling in hot water as presented in graph in Fig.4. The comparison of the tensile strength result can be observed in Table 1 and Table II.

TABLE I

THE TENSILE STRENGTH OF ATTACUS ATLAS FIBER DEGUMMED WITH CONVENTIONAL TREATMENT( BOILED IN HOT WATER)

\begin{tabular}{cccc}
\hline Silk type & $E(\mathrm{MPa})$ & $\varepsilon_{\mathrm{u}}$ & $\sigma_{\mathrm{u}}(\mathrm{MPa})$ \\
\hline A. atlas & $298 \pm 63.42$ & $0.17 \pm 0.020$ & $51 \pm 14.69$ \\
\hline
\end{tabular}

TABLE II

TENSILE STRENGTH OF ATTACUS ATLAS FIBER DEGUMMED WITH NAOH TREATMENT

\begin{tabular}{cccc}
\hline Silk type & $E(\mathrm{MPa})$ & $\varepsilon_{\mathrm{u}}$ & $\sigma_{\mathrm{u}}(\mathrm{MPa})$ \\
\hline A. atlas & $604 \pm 36.65$ & $0.17 \pm 0.012$ & $101 \pm 13.28$ \\
\hline
\end{tabular}

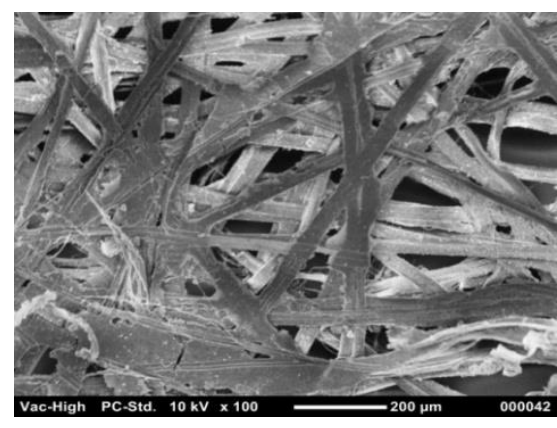

Fig 2. Scanning Electron Micrograph (SEM) of Attacus atlas cocoon before degumming with $\mathrm{NaOH}$ (raw material)

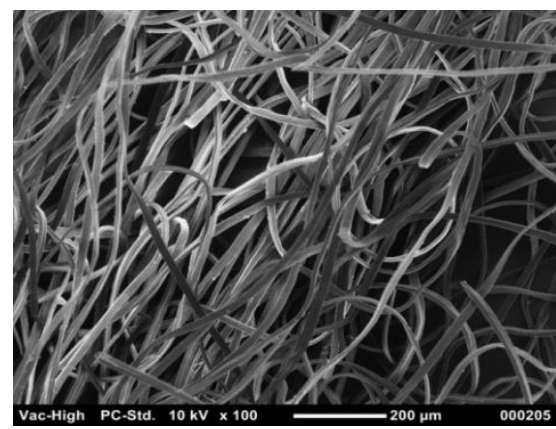

Fig. 3. Scanning Electron Micrograph (SEM) of fibner obtained from cocoon of Attacus atlas after degumming with $\mathrm{NaOH}$

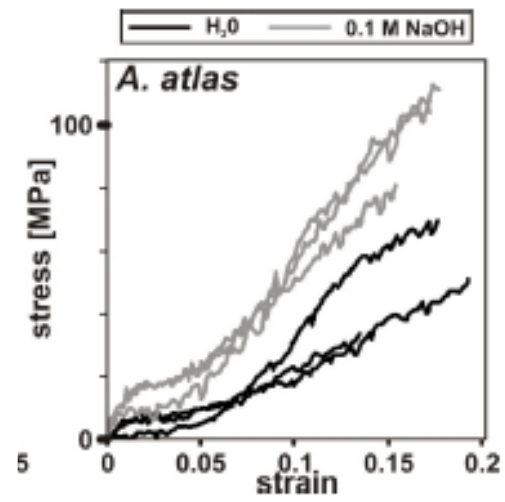

Fig. 4. Tensile test result. It is found that degumming with $\mathrm{NaOH}$ is found having higher tensile strength compared with the one with conventional degumming method of boiling in hot water

Biocompatibility testing of Attacus atlas fiber with $0.1 \mathrm{M} \mathrm{NaOH}$ treatment indicate that human cell osteosarcoma cell line (U2OS) able to attach and grow on the surface of the fiber in the next 6 days. The fiber is fully covered with U2OS cell that indicate the fiber having good biocompatibility (Fig.5)

It was discovered in the previous research that Attacus atlas and other species from family Saturniidae containing high calcium oxalate [19]. In this research with $0.1 \mathrm{NaOH}$ the mass of the fiber can be reduced up to $20 \%$ from initial condition. This data indicates that the degumming process with $0.1 \mathrm{M} \mathrm{NaOH}$ not only can 
eliminate the sericin but also the tanning process to occur that influents the cross linking of the protein [20,21,22].

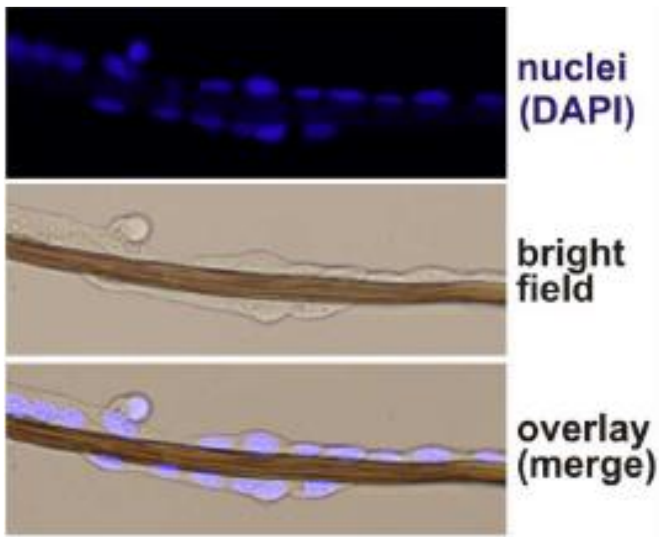

Fig. 5. Excellent biocompatible fiber is found after $\mathrm{NaOH}$ treatment of Atacus atlas fiber. The fiber is found covered entirely with human cell of U2OS

\section{CONCLUSION}

It can be concluded that $\mathrm{NaOH}$ treatment is suitable method for degumming of Attacus atlas cocoon. The precise concentration is found at $0.1 \mathrm{M} \mathrm{NaOH}$. With degumming method, the fiber is found having excellent biocompatible to human cell. The fiber also is found having better tensile strength compared with if degummed with conventional way by boiling in hot water.

\section{ACKNOWLEDGMENT}

This research was supported by Scheme of Penelitian Kerjasama Luar Negri PNBP Udayan University 2016 together with Czech Science Foundation Project P108/12/G108.

\section{REFERENCES}

[1] J. G. Hardy and T. R. Scheibel. 2010. Composite materials based on silk proteins, Prog Polym Sci 35: 1093-1115.

[2] X. Zhang, M.G. Reagan and D. L. Kaplan. 2009. Electrospun silk biomaterial scaffolds for regenerative medicine, Adv Drug Deliver Rev. 61: 988-1006.

[3] Y. Wang, H. J. Kim, Vunjak-Novakovic, and D. L. Kaplan. 2006. Stem cell-based tissue engineering with silk biomaterials, Biomaterials, 27: 6064-6082.

[4] B. Panilaitis, G. H. Altman, J. Chen, H. J. Jin, V. Karageorgiou, and D.L. Kaplan. 2003. Macrophage responses to silk, Biomaterials 24: 3079-3085.

[5] L. Meinel, S. Hofmann, V. Karageorgiou,, KirkerHead, McCool, and G. Gronowicz. 2005. The inflammatory responses to silk films in vitro and in vivo, Biomaterials 26: 147-55.

[6] F. Vollrath and D. Porter. 2009. Silks as ancient models for modern polymers, Polymer 50:5623-5632.
[7] J. Magoshi, Y. Magoshi, S. J. Nakamura. 1985. Liquid crystal, and fiber formation of silk fibroin, Appl Polym Symp, 41: 187-204.

[8] M. Mondal and K. Rivedy. 2007. The silk proteins, sericin and fibroin in silkworm Bombyx mori, Linna review, Caspian J. Environ Sci, 5: 63-76.

[9] D. N. Rockwood, Preda, R.C., Yuce, T. , Wang, L. X. , Lovett, M.L. ,dan Kaplan, D.L. 2011. Materials fabrication from Bombyx mori silk fibroin, Nat Protoc, 6: 1612-1631,

[10] C. Acharya., S. K. Ghosh and S. C. Kundu. 2009. Silk fibroin film from non-mulberry tropical tasar silkworms: A novel substrate for in vitro fibroblast culture, Acta Biomater, 5: 429-437.

[11] C. Patra, S. Talukdar, T. Novoyatleva, S.R. Velagala, C. Mühlfeld, and B. Kundu, B. 2012. Silk protein fibroin from antheraea mylitta for cardiac tissue engineering, Biomaterials, 33: 2673-2680.

[12] A. Datta, A. K. Ghosh, and S .C. Kundu. 2001. Differential expression of the fibroin gene in developmental stages of silkworm, antheraea mylitta (saturniidae), Comp Biochem Physiol B Biochem Mol Biol .129: 197-204.

[13] C. J. Fu, D. Porter, X. Chen, F. Vollrath, and Z. Shao. 2011. Understanding the mechanical properties of antheraea pernyi Silk from primary structure to condensed structure of the protein, Adv Funct Mater, 21: 729-737.

[14] M. Ho, H. Wang and L. Kin-tak. 2012. Effect of degumming time on silkworm silk fibre for biodegradable polymer composites, Appl Surf Sci 258: 3948-3955.

[15] P. Jiang, H. F. Liu, C. H. Wang, L .Z. Wu, J. G. Huang and C. Guo. 2006. Tensile behavior and morphology of differently degummed silkworm cocoon silk fibres, Mater Lett, 60: 919-925.

[16] G. V. Guinea, M. Elices, J .I. Rea, L. S. Guiterrez, and J .P. Riguerio. 2005. Reproducibility of the tensile properties of spider (Argiope trifasciata) silk obtained by forced silking, J Exp Zool, 303A: 37-44.

[17] J. P. Rigueiro, M. Elices, J. Llorca, C. Viney. 2001. Tensile properties of attacus atlas silk submerged in liquid media, J Appl Polym Sci. 82: 53-62.

[18] P. Poza, J. P. Rigueiro, M. Elices, and J. Llorca. 2002. Fractographic analysis of silkworm and spider silk, Eng Fract Mech, 69: 1035-1048.

[19] T. Gheysens,. A. Collins, S. Raina, F. Vollrath, and D. P. Knight. 2011. Demineralization enables reeling of wild silkmoth cocoons, Biomacromolecules 12: 2257-2266.

[20] P. C .J. Brunet, and B. C. Coles. 1974. Tanned silks, Proc. R Soc Lond B Biol Sci, 187: 133-170.

[21] D. J. Raven, C. Earland, M. Little, 1971. Occurrence of dityrosine in Tussah silk fibroin and keratin, Biochim Biophys Acta, 251: 96-99.

[22 ] S. Inoue, K. Tanaka, F. Arisaka, S. Kimura, K. Ohtomo, S. Mizuno. 2000. Silk fibroin of Bombyx mori is secreted, assembling a high molecular mass elementary unit consisting of $\mathrm{H}$-chain, L-chain, and P25, with a 6:6:1 molar ratio, J Biol Chem 275: 40517-40528. 